8 - ORIGINAL ARTICLE

ISCHEMIA-REPERFUSION

\title{
Protective effect of metformin on testicular ischemia/reperfusion injury in rats ${ }^{1}$
}

\author{
Ahmad Asghari', Ghasem AkbariI ${ }^{\mathrm{I}}$, Afshin Meghdadi ${ }^{\mathrm{II}}$, Pejman Mortazavi ${ }^{\mathrm{IV}}$ \\ DOI: http://dx.doi.org/10.1590/S0102-865020160060000008 \\ IAssistant Professor, Department of Clinical Science, Science and Research Branch, Islamic Azad University, Tehran, Iran. Design and supervised all \\ phases of the study, manuscript writing. \\ IIAssistant Professor, Department of Clinical Science, Science and Research Branch, Islamic Azad University, Tehran, Iran. Design of the study, \\ analysis and interpretation of data. \\ III Graduate student, Science and Research Branch, Islamic Azad University, Tehran, Iran. Technical procedures, acquisition and interpretation of data.

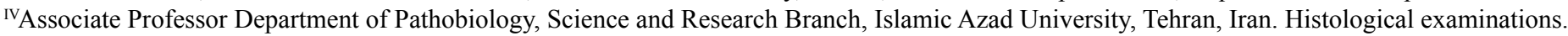

\begin{abstract}
PURPOSE: To investigate the protective effect of metformin on testicular ischemia/reperfusion (I/R) injury in rats.

METHODS: Eighteen adult male Wistar rats were randomly divided into three experimental groups (n=6), as follows: Sham, I/R, and Metformin. 1-hour ischemia was induced by the left testicular artery and vein clipping followed by 7 days of reperfusion. Metformin $(100 \mathrm{mg} / \mathrm{kg}$ ) was administrated orally for 7 days via oral gavage after ischemic period. At the end of trial, the left testis was removed for histological analysis and oxidative stress measurement.

RESULTS: I/R reduced superoxide dismutase (SOD) activities and testicular Johnsen's scores accompanied by an elevation in malondialdehyde (MDA) and myeloperoxidase (MPO) levels in comparison with the sham group $(P<0.05)$. Compared to I/R group, metformin restored testicular Johnsen's scores, SOD activity, MDA and MPO levels $(P<0.05)$.
\end{abstract}

CONCLUSION: Metformin has a protective effect against I/R injury on the testis.

Key words: Testis. Ischemia. Reperfusion. Metformin. Rats. 


\section{Introduction}

Torsion of the spermatic cord is a common urologic emergency among infants and adolescents. It requires early diagnosis and surgical intervention to prevent subfertility and infertility ${ }^{1}$. Testicular injury resulting from spermatic cord torsion/ detorsion resembles the phenomenon of ischemia/reperfusion $(\mathrm{I} / \mathrm{R})^{2}$. It has been demonstrated that spermatic cord torsion in the rat causes permanent aspermatogenesis ${ }^{2}$. This loss of spermatogenesis has been shown to be due to germ cell-specific apoptosis $^{3,4}$. I/R of the testis stimulates an intra-cellular signaling cascade in the testicular endothelial cells that results in neutrophil recruitment, an increase in intra-testicular reactive oxygen species (ROS), and eventual germ cell-specific apoptosis ${ }^{3,5,6}$. Although the results are not conclusive, several anti-inflammatory drugs ${ }^{7}$ or antioxidants and free radical scavengers ${ }^{8-10}$ have been used to prevent such I/R injury in testis.

Metformin has been used in the management of type 2 diabetes for many years and its glucose-lowering effect is well-established. Metformin also has a beneficial effect on the cardiovascular system. It has been confirmed that metformin relieves inflammatory responses following cardiac ischemia and protects cardiac function ${ }^{11}$. Wang et al. ${ }^{12}$ found that low doses of metformin may attenuate renal $\mathrm{I} / \mathrm{R}$ injury by increasing the energy supply to the ischemic tissue and reducing the expression of inflammatory cytokines. To our knowledge, no study has investigated the role of metformin in testicular I/R injury. In the present study, we evaluated the effect of metformin on biochemical and histopathologic changes in the testicular tissue in rats.

\section{Methods}

All experimental procedures were conducted according to international ethics guidelines and were previously locally approved (reference code 034-2/2015).

Eighteen adult male Wistar rats aged 10-12 weeks (250$350 \mathrm{~g}$ ), were obtained from the Pasteur Institute of Iran. The rats were maintained with free access to regular food and water, at $22 \pm 1^{\circ} \mathrm{C}$ under a 12 -h light/dark cycle.

The animals were randomly divided into three experimental groups, each with six rats: sham group were subjected to all operative procedures, except vessels occlusion. I/R group were undergoing 1-hour of ischemia and 7 days of reperfusion. Metformin group were received oral administration of $100 \mathrm{mg} / \mathrm{kg}^{13}$ metformin in $0.9 \%$ saline solution for 7 days by gavage technique after ischemic period.
The rats were fasted overnight before the experiments, but were given free access to water. They were weighed and anesthetized using an intramuscular injection of ketamine hydrochloride $10 \%$ and xylazine hydrochloride $2 \%(50 \mathrm{mg} / \mathrm{kg}$ and $10 \mathrm{mg} / \mathrm{kg}$, respectively) ${ }^{14}$. During the operations, additional doses were administered if necessary.

\section{Experimental protocol}

All operations were performed under sterile conditions. An abdominal incision was made; then the testicular artery and vein of the left testis were occluded with a mini vascular clamp for 1-hour; after this process, the clamp was removed and the organ was allowed to reperfusion for 7 days. Sham operations were performed in a similar fashion, except the vessels were not clamped.

\section{Samples collection}

The rats were euthanized by overdose of pentobarbital injection $(300 \mathrm{mg} / \mathrm{kg}$, i.p.) at the end of the reperfusion period. The left testis was harvested, cleared of adhering connective tissue. First, each testis was divided into two by a section and one half was fixed in Bouin's solution. The second half was stored at $-80^{\circ} \mathrm{C}$ for the biochemical analysis.

\section{Preparation of testicular tissue homogenates}

The samples were washed three times in cold normal saline solution $(0.9 \%)$. Then, the tissues were homogenized in ice-cold Tris- $\mathrm{HCl}$ buffer solution within a homogenizer for $2 \mathrm{~min}$ at $11.200 \times \mathrm{g}$. The homogenate was centrifuged at $3500 \times \mathrm{g}$ $\left(4^{\circ} \mathrm{C}\right)$ for $60 \mathrm{~min}$, and supernatant was obtained. The levels of myeloperoxidase (MPO) were determined in the supernatant, and malondialdehyde (MDA) levels were studied in the homogenate. For a further extraction procedure, the supernatant was extracted in ethanol/chloroform mixture $(5 / 3 \mathrm{v} / \mathrm{v})$. After a second centrifugation at $3500 \times \mathrm{g}$ for $20 \mathrm{~min}$, the clear upper layer was taken and used for superoxide dismutase (SOD) activity determination ${ }^{15}$.

\section{Biochemical analysis}

The principle of the SOD activity determination method was based on the inhibition of nitroblue tetrazolium reduction described by Sun et al. ${ }^{16}$ and modified by Durak et al. ${ }^{17}$. One unit of SOD was defined as the enzyme activity causing $50 \%$ inhibition 
in the nitroblue tetrazolium reduction rate. The SOD activity was expressed as $\mathrm{U} / \mathrm{mg}$ tissue.

The MDA levels in testicular tissues were analyzed by a method based on the reaction with thiobarbituric acid at $95^{\circ} \mathrm{C}^{18}$. In the thiobarbituric acid test reaction, MDA or MDA-like substances and thiobarbituric acid react together to produce a pink pigment with an absorption maximum of $532 \mathrm{~nm}$. The results were expressed as $\mathrm{nmol} / \mathrm{g}$ tissue.

Testicular injury was quantified by measuring testicular MPO activity, using a protocol modified from the previous report ${ }^{19}$. The MPO activity was determined after adding O-dianisidine dihydrochloride and hydrogen peroxide. The MPO activity was expressed as $\mathrm{U} / \mathrm{g}$ tissue.

Oxidative stress biomarkers were determined by using kits (Randox Laboratories, Ltd., UK) according to the manufacturer's instructions.

\section{Histologic evaluation}

The testes were fixed in Bouin's solution $(7.5 \mathrm{~mL}$ saturated picric acid, $2.65 \mathrm{~mL}$ glacial acetic acid and $2.5 \mathrm{~mL}$ $7 \%$ formaldehyde), post-fixed in 70\% alcohol, and embedded in paraffin blocks. Sections $(5 \mu \mathrm{m})$ were obtained, deparaffinized, and stained with hematoxylin-eosin. The testicular tissue was evaluated in random order with standard light microscopy by an observer who was unaware as to which group the rat had belonged. Histological findings in seminiferous tubule were evaluated according to Johnsen's scoring system (Table 1$)^{20}$.

TABLE 1 - Histological grading according to Johnsen's scoring system.

\begin{tabular}{|c|c|}
\hline Score-10 & $\begin{array}{l}\text { (Complete spermatogenesis with many } \\
\text { spermatozoa present) }\end{array}$ \\
\hline Score-9 & $\begin{array}{l}\text { (Slightly impaired spermatogenesis with many } \\
\text { late spermatids, disorganized epithelium) }\end{array}$ \\
\hline Score- 8 & $\begin{array}{c}\text { (Less than five spermatozoa per tubule, few late } \\
\text { spermatids) }\end{array}$ \\
\hline Score-7 & $\begin{array}{c}\text { (No spermatozoa, no late spermatids, many early } \\
\text { spermatids) }\end{array}$ \\
\hline Score-6 & $\begin{array}{l}\text { (No spermatozoa, no late spermatids, few early } \\
\text { spermatids) }\end{array}$ \\
\hline Score-5 & $\begin{array}{l}\text { (No spermatozoa or spermatids, many } \\
\text { spermatocytes) }\end{array}$ \\
\hline Score-4 & $\begin{array}{c}\text { (No spermatozoa or spermatids, few } \\
\text { spermatocytes) }\end{array}$ \\
\hline Score-3 & (Spermatogonia only) \\
\hline Score-2 & (No germinal cells, Sertoli cells only) \\
\hline Score-1 & (No seminiferous epithelium) \\
\hline
\end{tabular}

\section{Statistical analysis}

All data was statistically analyzed using the statistical package for the social sciences (SPSS) version 18.0 (SPSS Inc., Chicago, IL, USA). The data were expressed as mean \pm standard deviation. Analysis of variance (ANOVA) was used for statistical analysis of data among all groups. A value of $\mathrm{p}<0.05$ was considered statistically significant.

\section{Results}

All rats survived without major complications. The values of SOD, MDA, and MPO of each group are shown in Table 2. When compared with the sham group, I/R reduced SOD activities accompanied by an elevation in MDA and MPO levels $(p<0.05)$. Metformin treatment significantly enhanced the SOD activity $(p<0.05)$. Metformin group had lower levels of tissue MDA and MOP levels than in $/ / R$ group, indicating a beneficial effect of treatment in metformin group.

The testicular Johnsen's score of all groups were shown in Table 2. The testes in the I/R group were found to markedly increase disorganization, sloughing and loss of maturation of germ cells when compared with the sham group (Figures 1 and 2). I/R and metformin showed testicular damage in the histopathologic examination, but specimens from $\mathrm{I} / \mathrm{R}$ group had a significantly greater histological injury $(\mathrm{p}<0.05)$ than metformin group (Figure $3)$. The scores of the treated group were significantly higher than that of the I/R group.

TABLE 2 - Tissue oxidative stress activities and testicular Johnsen's scores of the groups.

\begin{tabular}{ccccc}
\hline Groups & $\begin{array}{c}\text { SOD (U/ } \\
\text { mg tissue) }\end{array}$ & $\begin{array}{c}\text { MDA } \\
\text { (nmol/g } \\
\text { tissue) }\end{array}$ & $\begin{array}{c}\text { MPO (U/g } \\
\text { tissue) }\end{array}$ & $\begin{array}{c}\text { Johnsen's } \\
\text { score }\end{array}$ \\
\hline Sham & $3.68 \pm 0.18$ & $\begin{array}{c}127.54 \pm \\
14.42\end{array}$ & $4.22 \pm 0.23$ & $9.95 \pm 0.16$ \\
Ischemia/ & $2.65 \pm 0.21^{*}$ & $\begin{array}{c}170.81 \pm \\
19.13^{*}\end{array}$ & $5.37 \pm 0.82^{*}$ & $2.99 \pm 0.08^{*}$ \\
reperfusion & & $\begin{array}{c}146.24 \pm \\
14.15\end{array}$ & $4.61 \pm 0.55$ & $8.30 \pm 0.52$ \\
Metformin & $3.19 \pm 0.20$ & & \\
\hline
\end{tabular}

${ }^{*} \mathrm{p}<0.05$ compared with the other groups. 


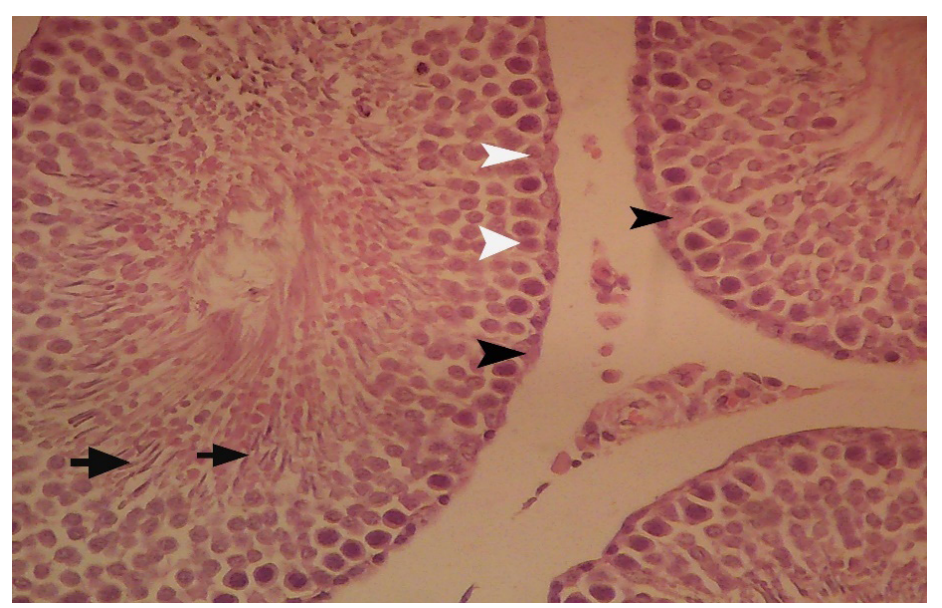

FIGURE 1 - The representative tissue section of sham rats (H\&E, Original magnification $\times 640$ ). Orderly spermatogenetic maturation and mature spermatids in the lumen. Spermatozoids (arrow), sertoli cell (black arrowheads) and spermatogoni (white arrowheads).

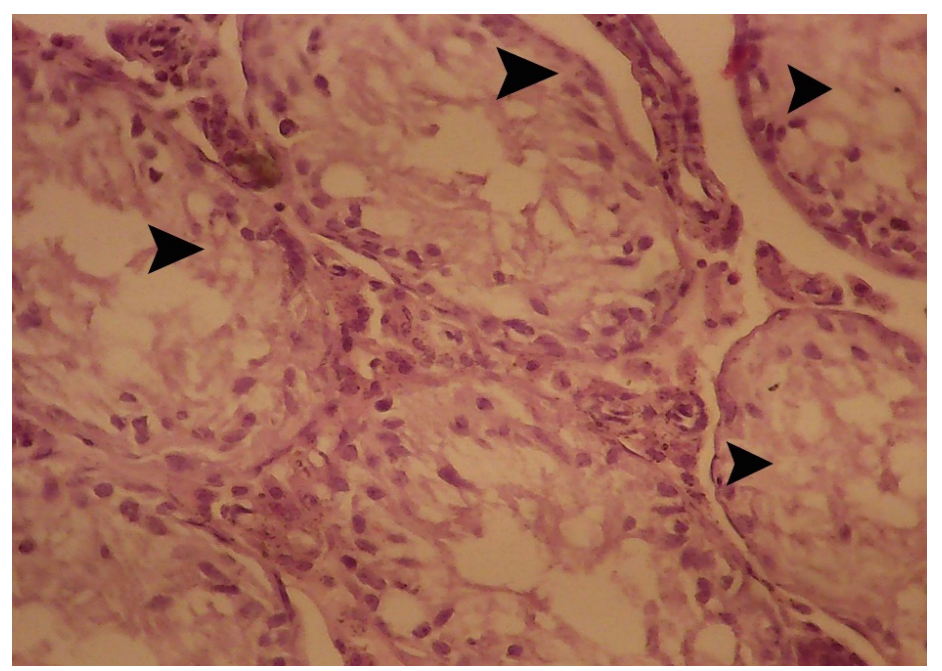

FIGURE 2 - The representative tissue section of ischemia-reperfusion $(\mathrm{I} / \mathrm{R})$ rats $(\mathrm{H} \& \mathrm{E}$, Original magnification $\times 640)$. Complete maturation arrest with immature spermatogonia lying along the tubule basement membrane. The large number of seminiferous tubular cells were destroyed (arrowheads) by I/R.

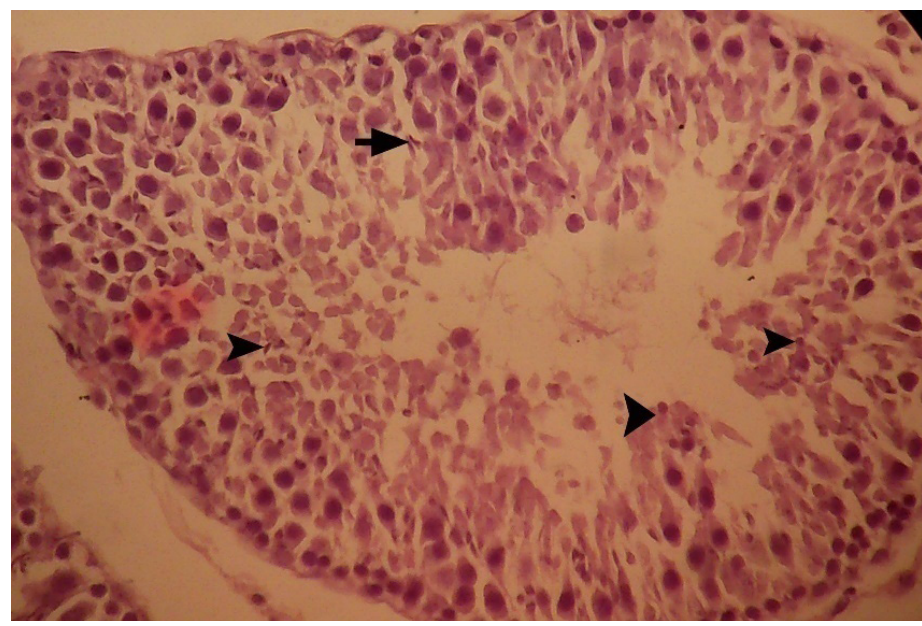

FIGURE 3 - The representative tissue section of metformin rats (H\&E, Original magnification $\times 640$ ). Spermatogoni (black arrowheads) and spermatozoids (arrow).

\section{Discussion}

Spermatic cord torsion-detorsion is an $\mathrm{I} / \mathrm{R}$ process of the testis. In the course of $\mathrm{I} / \mathrm{R}, \mathrm{ROS}$ are overproduced. The main cause of tissue injury after $I / R$ is $\operatorname{ROS}^{21}$. ROS production seems to possess two phases in ischemic-reperfused tissues. The first phase occurs immediately after reperfusion, extends for a few hours and is a typical oxidative stress situation, reversible in terms of cellular injury ${ }^{2,8}$. MDA is the end product of lipid peroxidation and is a well-known parameter for determining the increased free radical formation in post-ischemic tissue ${ }^{22,23}$. SOD and glutathione peroxidase are major enzymes that scavenge harmful ROS in male reproductive organ $\mathrm{s}^{24}$. Previous studies have shown similar findings that $I / R$ leads to increased MDA and inactivation of antioxidant enzymes in rat testes ${ }^{23,25,26}$. ROS stimulate the release and the formation of various inflammatory mediators with powerful chemotactic potentia ${ }^{26}$. These mediators lead to leukocyte activation. Increase in MPO activity in tissue may reflect activation of neutrophils in the I/R condition ${ }^{27}$.

Metformin is a biguanide drug which improves the sensitivity to insulin, increases the insulin-stimulated uptake and utilization of glucose, reduces basal hepatic glucose production, causes weight reduction and decreases hunger ${ }^{28}$. Recent studies have recommended the use of this drug for kidney protection. These studies have suggested that metformin has antioxidant activities, too $^{29,30}$. The apoptosis, induced by oxidative stress, in endothelial cells was reduced and the vascular dysfunction was prevented following metformin therapy ${ }^{28}$. Recently, the ameliorative effect of metformin was demonstrated against $\mathrm{I} / \mathrm{R}$ induced injury in rats ${ }^{31}$. Indeed, there is evidence that, when metformin is used alone, the beneficial effect of metformin might be due to its mild inhibition of the mitochondrial respiratory chain. It is also suggested that metformin treatment may attenuate the increase in MDA and total ROS generation and restore the decrease in both enzymatic and non-enzymatic antioxidant ${ }^{31-33}$. We determined that metformin restored SOD activity, MDA and MPO levels.

In this study, we evaluated testicular injury by observing changes in tubular architecture and also by applying Johnsen's scoring system. Using a rat model it has been demonstrated that testicular $\mathrm{I} / \mathrm{R}$ caused a significant decrease in testicular score $^{34}$. In our experiment, we observed morphologic changes in testes following testicular I/R. The Johnsen's criteria decreased significantly in $\mathrm{I} / \mathrm{R}$ groups compared with the sham animals. Treatment of metformin had a significant benefit to the tubular architecture or Johnsen's score after I/R. 


\section{Conclusion}

Metformin played a role in alleviating the inflammatory responses, which was beneficial in protecting the testis from ischemia-reperfusion injury.

\section{References}

1. Akgur FM, Kilinc K, Aktug T. Reperfusion injury after detorsion of unilateral testicular torsion. Urol Res. 1993;21:395-9. PMID: 8171761.

2. Turner TT, Brown KJ. Spermatic cord torsion: loss of spermatogenesis despite return of blood flow. Biol Reprod. 1993 Aug;49:401-7. PMID: 8373967.

3. Turner TT, Tung KS, Tomomasa H. Acute testicular ischemia results in germ cell-specific apoptosis in the rat. Biol Reprod. 1997 Dec;57:1267-74. PMID: 9408230.

4. Lysiak JJ, Turner SD, Turner TT. Molecular pathway of germ cell apoptosis following ischemia/reperfusion of the rat testis. Biol Reprod. 2000 Nov;63:1465-72. PMID: 11058553.

5. Lysiak JJ, Turner SD, Nguyen QA, Singbartl K, Ley K, Turner TT. Essential role of neutrophils in germ cell-specific apoptosis following ischemia/ reperfusion injury of the mouse testis. Biol Reprod. 2001 Sep;65:718-25. PMID: 11514333.

6. Lysiak JJ, Nguyen QA, Kirby JL, Turner TT. Ischemia-reperfusion of the murine testis stimulates the expression of proinflammatory cytokines and activation of c-jun $N$-terminal kinase in a pathway to E-selectin expression. Biol Reprod. 2003 Jul;69:202-10. PMID: 12620934.

7. Mogilner JG, Lurie M, Coran AG, Nativ O, Shiloni E, Sukhotnik I. Effect of diclofenac on germ cell apoptosis following testicular ischemia-reperfusion injury in a rat. Pediatr Surg Int. 2006 Jan;22:99-105. PMID: 16283337.

8. Filho DW, Torres MA, Bordin AL, Crezcynski-Pasa TB, Boveris A. Spermatic cord torsion, reactive oxygen and nitrogen species and ischemia-reperfusion injury. Mol Aspects Med. 2004 FebApr;2:199-210. PMID: 15051328.

9. Cay A, Alver A, Kucuk M, Isik O, Eminagaoglu MS, Karahan SC, Deger O. The effects of $N$-acetylcysteine on antioxidant enzyme activities in experimental testicular torsion. J Surg Res. 2006 Apr;131:199-203. PMID: 16412470.

10. Unsal A, Eroglu M, Avci A, Cimentepe E, Guven C, Derya Balbay M, Durak I. Protective role of natural antioxidant supplementation on testicular tissue after testicular torsion and detorsion. Scand J Urol Nephrol. 2006;40:17-22. PMID: 16452050.

11. Charlon V, Boucher F, Mouhieddine S, Deleiris J. Reduction of myocardial infarct size by metformin in rats submitted to permanent left coronary-artery ligation. Diabetes Metab. 1988;14:591-5.

12. Wang ZS, Liu XH, Wang M, Jiang GJ, Qiu T, Chen ZY, Wang L. Metformin attenuated the inflammation after renal ischemia/ reperfusion and suppressed apoptosis of renal tubular epithelial cell in rats. Acta Cir Bras. 2015 Sep;30(9):617-23. PMID: 26465106.

13. Barthelmebs M, Wiernsperger N, Krieger J, Rapin J, Radziuk J, Grima M, Imbs JI. Mild acute renal failure potentiates metformin accumulation in the diabetic rat kidney without further impairment of renal function. Diabetes Metab. 2003 Apr;29(2):163-70.

14. Takhtfooladi HA, Takhtfooladi MA, Karimi P, Asl HA, Mobarakeh SZ. Influence of tramadol on ischemia-reperfusion injury of rats' skeletal muscle. Int J Surg. 2014;12(9):963-8. PMID: 25062899.

15. Parlaktas BS, Atilgan D, Gencten Y, Akbas A, Markoc F, Erdemir $\mathrm{F}$, Ozyurt H, Uluocak N. The effects of carvedilol on ischemia- reperfusion injury in the rat testis. Int Braz J Urol. 2014 JanFeb;40(1):109-17. PMID: 24642157.

16. Sun Y, Oberley LW, Li Y. A simple method for clinical assay of superoxide dismutase. Clin Chem. 1988 Mar; 34(3):497-500. PMID: 3349599.

17. Durak I, Yurtarslanl Z, Canbolat O, Akyol O. A methodological approach to superoxide dismutase (SOD) activity assay based on inhibition of nitroblue tetrazolium (NBT) reduction. Clin Chim Acta. 1993 Jan;214:103-4. PMID: 8453769.

18. Wasowicz W, Nève J, Peretz A. Optimized steps in fluorometric determination of thiobarbituric acid reactive substances in serum: importance of extraction $\mathrm{pH}$ and influence of sample preservation and storage. Clin Chem. 1993 Dec;39:2522-6. PMID: 8252725.

19. Yang CH, Tsai PS, Wang TY, Huang CJ. Dexmedetomidineketamine combination mitigates acute lung injury in haemorrhagic shock rats. Resuscitation. 2009 Oct;80:1204-10. PMID: 19608326.

20. Johnsen SG. Testicular biopsy score count-A method for registration of spermatogenesis in human testis: normal values and result in 352 hypogonadal males. Hormones. 1970;1:2-25. PMID: 5527187.

21. Takhtfooladi MA, Shahzamani M, Takhtfooladi HA, Moayer F, Allahverdi A. Effects of light-emitting diode (LED) therapy on skeletal muscle ischemia reperfusion in rats. Lasers Med Sci. 2015 Jan;30(1):311-6. PMID: 25274196.

22. Takhtfooladi MA, Jahanshahi A, Sotoudeh A, Daneshi MH, Khansari $\mathrm{M}$, Takhtfooladi HA. The antioxidant role of $\mathrm{N}$-acetylcysteine on the testicular remote injury after skeletal muscle ischemia and reperfusion in rats. Pol J Pathol. 2013 Oct;64(3):204-9. PMID: 24166607.

23. Gezici A, Ozturk H, Buyukbayram H, Ozturk H, Okur H. Effects of gabexate mesilate on ischemia-reperfusion-induced testicular injury in rats. Pediatr Surg Int. 2006 May;22(5):435-41. PMID: 16557390.

24. Pekcetin C, Ergur BU, Kiray M, Bagriyanik A, Tugyan K, Erbil G, Ozogul C. The protective effects of trimetazidine on testicular ischemia and reperfusion injury in rats. Pediatr Surg Int. 2007 Nov;23(11):1113-8. PMID: 17704922.

25. Salmasi AH, Beheshtian A, Payabvash S, Demehri S, Ebrahimkhani MR, Karimzadegan M, Bahadori M, Pasalar P, Dehpour AR. Effect of morphine on ischemia-reperfusion injury: experimental study in testicular torsion rat model. Urology. 2005 Dec;66(6):1338-42. PMID: 16360480.

26. Takhtfooladi MA, Moayer F, Takhtfooladi HA. Beneficial effect of pentoxifylline into the testis of rats in an experimental model of unilateral hindlimb ischemia/reperfusion injury. Int Braz J Urol. 2015 May-Jun;41(3):576-83. PMID: 26200554.

27. Takhtfooladi MA, Asghari A, Takhtfooladi HA, Shabani S. The protective role of curcumin on testicular tissue after hindlimb ischemia reperfusion in rats. Int Urol Nephrol. 2015 Oct;47(10):1605-10. PMID: 26347078.

28. Rosen P, Wiernsperger NF. Metformin delays the manifestation of diabetes and vascular dysfunction in Goto-Kakizaki rats by reduction of mitochondrial oxidative stress. Diabetes Metab Res Rev. 2006 Jul-Aug;22:323-30. PMID: 16444763.

29. Cicero AF, Tartagni E, Ertek S. Metformin and its clinical use: new insights for an old drug in clinical practice. Arch Med Sci. 2012 Nov;8:907-17. PMID: 23185203.

30. Detaille D, Guigas B, Chauvin C, Batandier C, Fontaine E, Wiernsperger N, Leverve X. Metformin prevents high-glucoseinduced endothelial cell death through a mitochondrial permeability transition-dependent process. Diabetes. 2005 Jul;54:2179-87. PMID: 15983220.

31. Taheri N, Azarmi Y, Neshat M, Garjani A, Doustar Y. Study the effects of metformin on renal function and structure after unilateral ischemia-reperfusion in rat. Res Pharm Sci. 2012;7:77. PMCID: PMC3658943. 
Asghari A et al.

32. Rafieian Kopaei M, Baradaran A, Merrikhi A, Nematbakhsh M, Madihi Y, Nasri H. Efficacy of co-administration of garlic extract and metformin for prevention of gentamicin-renal toxicity in wistar rats: a biochemical study. Int J Prev Med. 2013 Mar;4:258-64. PMID: 23626881.

33. Sung JY, Choi HC. Metformin-induced AMP-activated protein kinase activation regulates phenylephrine-mediated contraction of rat aorta. Biochem Biophys Res Commun. 2012 May;421:599-604. PMID: 22525678.

34. Tunckiran A, Cayan S, Bozlu M, Yilmaz N, Acar D, Akbay E. Protective effect of vascular endothelial growth factor on histologic changes in testicular ischemia-reperfusion injury. Fertil Steril. 2003 Aug;84(2):468-73. PMID: 16084892.

\section{Correspondence:}

\section{Ahmad Asghari}

Department of Clinical Science, Science and Research Branch

Islamic Azad University, Tehran Iran

Phone: 00989144147924

Fax: 00982144868536

dr.ahmad.asghari@gmail.com

Received: Feb 22, 2016

Review: Apr 19, 2016

Accepted: May 18, 2016

Conflict of interest: none

Financial source: none

${ }^{1}$ Research performed at Department of Clinical Science, Faculty of Specialized Veterinary Sciences, Islamic Azad University, Tehran, Iran. 